KRZYSZTOF GORLACH - MARTYNA WIERZBA-KUBAT - ANNA JASTRZĘBIEC-WITOWSKA - PIOTR NOWAK ${ }^{1}$

Local Food as an Agent of Regional RuRAL DeVELOPMENT

THREE EXAMPLES FROM the MAtOPOLSKA REgION IN POLAND

DOI: $10.18030 /$ SOCIO.HU.2016EN.176

\title{
ABSTRACT
}

The article presents current issues and research problems concerning the problems of food in the area of sociology and other social, humanistic, and political sciences. Since the lack of analytical approaches other than the traditional division between scientific disciplines, the authors suggest a new approach based on the reviewed literature, namely: the so called intra-human and extra-human approaches. In this paper the authors use the extra-human approach combined with the neo-endogenous perspective to analyze three empirical cases of the following regional products, namely: oscypek cheese, zatorski karp (local pound fish), and lisiecka kiełbasa (regional sausage).

Key words: food studies, rural development, neo-endogenous development, regional food, food chains 


\section{Local Food as an Agent of Regional Rural Development \\ Three EXAMPLES FROM the MAŁOPOLSKA REgION IN POLAND}

\section{SOME INTRODUCTORY REMARKS}

Food seems to be an object of interest and study in many disciplines; for instance, one extensive international collection of papers published recently (Albala 2014) contains various perspectives and frames (humanistic, social, and political ones). All of these perspectives also incorporate some anticipation about the new agricultural research agenda in the current century (Kirschenmann 2014: 364-370).

Food might also be considered in various broader contexts related to forming the agenda of current social analyses, such as: politics and power; the nature and geography of malnutrition; globalization and development; national and sub-national perspectives; conflict and hunger; food and security; as well as some alternative visions (Young 2012). It is also worth emphasizing that major change in the contemporary world's food system might be treated as an effect of the current wave of globalization. As Young puts it: 'Corporate globalization has transformed the way food is produced and where it is produced. It has also transformed the type of food consumed and, frequently, where it is consumed. The global food business is very concentrated, and a great deal of power rests with a few global corporations who dominate the global food chain' (Young 2012: 144-145).

It is not an exaggeration to say that social conflicts resulting from the globalization of the food industry are both directly and indirectly responsible for food insecurity. Such conflicts are usually rooted in deep structural and geopolitical contexts resulting in the growing wave of refugees having limited access to healthy food (or even any kind of food at all). In such a context food also has to be treated as an important element of national sovereignty and security. Food is also used in many situations as a kind of weapon as well to put pressure on other actors in international relations. Based on these considerations we conducted some research to show the role of regional foods in the processes of regional development. In all cases presented below the regional products seem to be perceived as an important tool to stimulate a bottom-up approach to rural development. In each case one might observe the historical component bringing the product to the tradition of the particular locality. In this context each product is legitimized because of its tradition and quality, as well as its targetting towards the consumers, who are mainly tourists coming to the particular area. Local producers and local communities seem to meet requirements of extra-local (global) consumers, mainly global tourists, including those with postmodern personalities looking for new feelings and impressions concerning culinary tastes (Bauman, 1993). Three local products presented above in this paper can be found on the list of regional products issued by the Ministry of Agriculture and Rural Development. Their certificates can in fact impact the choices of consumers seeking authentic products. 


\section{PERSPECTIVES, FRAMES AND THEMES IN FOOD STUDIES IN SOCIAL SCIENCES: SOME MAJOR MESSAGES}

Coming back to the anthropology of food, the role of cooking in human evolution has been discussed extensively. Moreover, anthropologists have been focused on several other areas, notably archaeological investigations of feasting, historical studies of global commodity trade, and in-depth analyses of the food ways in various communities (Dirks-Hunter 2014: 3). It seems however, that sociologists have taken a much broader perspective in food studies.

Let us start with McIntosh (2014: 14-26), who sketches the panorama of historical studies, including the evolution of food consumption and family as well as cultural conflicts related to it. Then food studies contribute to the development of sociological theories. Several such theories have been mentioned, namely: agency theory, sociology of culture, social problems, social capital, and the family and social movements. In each case one might observe the analyses of various types of actors' (producers, processors, retailers, consumers, etc.) behaviour concerning different aspects of food problems. Moreover, the issues of production and especially those of consumption have been taken into consideration in the context of particular cultures treated as social tools dealing with various aspects of food problems. Some sociologists (Albala 2014, Goodman-DuPuis-Goodman 2014, Rosset 2006) further argue that food has become an important part of both social capital and social problems. Discussions of food and social problems deal on the one hand with issues of food scarcity and malnutrition, and on the other with diets and obesity experienced in many developed societies. When food issues are linked to social capital the role of food in the context of social relations is highlighted. There are also references to food security and trust in the area of market relationships in neighbourhoods and communities. In the light of the growing lack of trust in food offered by global retail networks, neighbourhoods and communities seem to be becoming a kind of trustworthy frame of food production and consumption. Families also seem to constitute an important 'food frame,' which is related not only with food production, but even more so with food consumption. Within this context one might discuss cooking, family meals, meal rituals, as well as roles of particular family members in the processes of meal cooking and serving. The issues of the diminishing importance of family meals, being replaced by 'eating outside of the home', have also been considered here. Food production and food consumption have been perceived as important issues by various types of social movements, both the traditional ones mainly focused on economic contexts of basic, and so-called healthy food accessibility, as well as new social movements dealing with some cultural and social issues of food, as exemplified by the Slow Food Movement.

The role of cooking food is also quite important in food studies. As Wrangham (2009) argues: '(...) cooking food made digestion easier and so the human gut could grow smaller compared to other non-human primates. The enormous energy previously spent on digestion then allowed the human brain to grow larger' (Cargill 2014: 41). Considering that, one might argue that the advantages of cooking food were not only limited to biological conditions of humans but also helped to develop their social and cultural abilities. The sociological overview should additionally include food studies, some studies on obesity, and poverty should also be added to the larger picture (for example Drewnowski 1996, see also: Cargill 2014: 42).

Nutritional anthropology is another conceptual and theoretical framework that should be presented 
here. As Chrzan (2014: 48) stresses: 'Nutritional anthropology traditionally has been defined as a combination of biological and cultural paradigms, which jointly are considered to determine food choice, consumption, and resulting nutriture.' Such a perspective shows that nutritional anthropology seems to be a kind of multidisciplinary approach to food issues. However, on the other hand, some social dimensions seem to be stressed by many authors. For Pelto, Goodman and Dufour (2000), nutritional anthropology deals with extreme omnivory, cooking as a specific human activity (compared to other primates, not to mention other animals), complex and carefully arranged systems of food distribution, as well as systems of food preferences and prohibitions. The latter issues are related to systems of belief and other social regulations pertaining to diets. This is also connected to the archaeology of food, which focuses on several historical aspects of food issues within human societies, such as the results of first farming practices, the domestication of various animals and its effect on human diets, and the growing appetite for sweets, fatty foods, spicy foods, alcoholic beverages and the like (Moore 2014: 74-75).

Another frame has been connected to the studies on journalism. For Rosner and Hesser (2014: 89) food journalism '(...) is a tremendously diverse category of nonfiction that is only minimally defined by genre or format; instead it applies to any sort of writing that deals with matters of food, cooking, food production, food culture, and the dozens of nooks and crannies in those categories.' Moreover, the authors say that such nonfictions might be a historical component or a type of instruction for anybody. They might also be humorous, critical, memoir-driven or even inspirational. However, what is important is that such writing cannot have an academic character and must be directed to a lay readership. Then, one should stress that food journalism might itself be an object of academic study, a kind of discourse that can be taken into consideration by social scientists and/or humanities academics conducting research on food issues.

The next humanistic perspective has focused on culinary history. As Albala (2014: 114) puts it simply, culinary history theorizes about the past via food practices. Further issues such as gender, class, race, ethnicity, and other social and cultural dimensions, which can be observed in human society, should be taken into consideration as well. While culinary history has been dominated by the so-called Western traditions, contemporary authors also include the role of African, Asian, Muslim, etc. culinary history in the contemporary globalized world. The cultural history of food (Valenze 2014) focuses on major historical and cultural changes in which food plays a rather supplemental role. In turn, the perspective of culinary history directly deals with changes concerning food production, eating etiquette, table manners, and so on. Another perspective known as 'philosophy and food' has some similarities to the issues mentioned above. As Heldke (2014: 135) frames it: 'Philosophy has only recently begun the formal study of food, although philosophers have been discussing food since Plato (...) questions of humans' relations to food have arisen quite naturally, even necessarily, for theorists challenging a certain historical prejudice against the body, practice, ordinary everydayness, and temporality'. The aesthetic significance of food has been given special consideration under this frame. Moreover, some other authors have focused on issues of eating as a social event and on recipes, developing some theoretical approaches to reasoning as well as emotions. Moreover, philosophers have been welcome in public discussions concerning food, especially pushing these debates beyond just moral dichotomies. Therefore, philosophical debate has reached beyond simple moral issues: organic foods or genetically modified foods. As Heldke (2014: 
136) concludes: 'Philosophy best contributes to public conversations about food not by solving or resolving ethical or aesthetic conundrums, but by problematizing the terms of those conundrums'.

The next perspective contains food and theology issues. Let us start with the statement by Grumett (2014: 159): 'Current work on food and theology is indebted to prior development in religious studies, social anthropology, and sociology'. This rather broad perspective points out three major elements characterizing this particular approach to food studies. The first one is connected to the already mentioned perspectives of sociology, anthropology, as well as culture. In this particular case theological perspective gives an additional dimension to food studies, namely: a kind of supernatural aspect to food practices treated as a peculiar aspect of human activities both historically and presently. The second one seems to be related to the sacred aspect of eating. For example, in the Christian tradition it might be the event of the last supper. That had not only an aspect of togetherness, i.e. having a meal during an important moment of Jewish tradition, but also started a particular rite in the Christian tradition. The last of these elements has to do significantly with food production. Quite unsurprisingly the role of farmers has been emphasized in theological and religious studies as those who take care of the land and also share the responsibility to feed others.

Under the humanities frame, the perspective of food and art has also been a subject of academic reflection. To quote Nygard who represents this perspective: 'Art is considered as a data set useful in the interrogation of food-related social history' (Nygard 2014: 169). Three main areas of analysis may also be distinguished in this particular perspective. The first one has been strongly connected to some already mentioned perspectives of culture, history, literature and theology. Nevertheless, food is sometimes treated as a kind of piece of art, which brings us to the second component of this perspective. Here, one might appreciate the whole process of food preparation and serving during some social events, which might be somehow related to the process of artists producing various types of art. Moreover, the arts seem to be important in the processes of designing tools used for the serving and eating of food as well, namely the design of cups, jars, etc.

Two other perspectives address connections between food studies and film, as well as television. They have a lot in common with perspectives concerning food and culture as well as food and literature. As Bower and Piontek (2014: 177) explain: 'Throughout cinematic history, food has played a part in all kinds of films, frequently revealing aspects of characters' emotions, identities, cultural backgrounds, fears, and aspirations'. In short, film is perceived here as an instrument for showing many social aspects of food production, cooking, as well as consumption/eating. A similar perspective has been developed in the studies concerning the relations between food and television. As Murray (2014: 187) frames it: 'The history of food on television is an old as the history of television itself. Descending from the cookery broadcasts of the radio era, food's enduring presence on television has been iterative yet varied, ranging from segmented on-air cooking demos and educational "howto" programs to celebrity-infused food competitions and narrow-casted lifestyle television for the foodie niche'. However, what is different in the case of television seems to lie in the planned efforts perceived in various shows, to suggest some particular food diets and habits that might be recognized as 'more healthy' than others.

The broad overview of food studies might point to at least two other perspectives. The first one is called 'interdisciplinary food studies' (Albala 2014: 199-291), while the second one is 'special topics in food studies' 
(Albala 2014: 293-378). In fact, there is no visible or significant difference between the two parts of this frame. In the first one, the authors discuss food studies programs, relations between food and American studies, folklore, food museums, relations between food and law, food studies and gender issues, relations between culinary arts as well as food service management. The areas of food and cultural studies and popular culture as well as relations between food and race deserve mentioning here as well. In the second part, the main frame contained several academic reflections that encompass food justice, relations between food studies and animal rights, qualitative and mixed method approaches to the exploration of the social dimensions of food and nutrition security that were mentioned earlier in this paper. Other areas of interest include: school food, food in tourism studies, food and senses, food and agriculture, as well as food and ethics.

We are not able to explain in what sense these last two perspectives provide a different framework to food than some other perspectives also presented briefly in this paper. In each case food has been conceptualized and analyzed in a particular context, namely: culture, religion, philosophy, nutrition, race, linguistics (Buccini 2014: 146-158), film, history, archaeology, anthropology, sociology, communication, psychology (Cargill 2014: 39-47), public health (Spark 2014: 65-73), journalism, literature (Fitzpatrick 2014: 122-134) art, television, food and communication (Lizie 2014: 27-38) and many others. Therefore the question arises: can food studies somehow be systematized?

\section{FOOD STUDIES-TWO GENERAL TRADITIONS AND TWO APPROACHES}

\section{Food studies in rural sociology: American and European traditions}

As already noted in this paper, significant sociological categories are used to describe numerous aspects of food phenomena. The humanistic or individual approach can be intertwined with broader social contexts in both European and U.S. perspectives that will briefly be described here.

Food studies have already established a strong presence in rural sociology, both in the United States and in Europe. While the American approach mostly focuses on community, citizenship, partnership, democracy, food-security, and globalization, European studies seem to prioritize theory. To some extent the bulk of both approaches combine theory with discussions underscoring the need for new, more suitable theoretical paradigms. Therefore we start our presentation with some examples from Rural Sociology, deeply connected with the American tradition, since that journal is an official periodical of the Rural Sociological Society (of North America).

The multidisciplinary approach is widely used in food risks assessment. Some authors have developed a model of interpersonal trust in the food system, taking into account estimates on pesticides, Salmonella and fat risks as well as psychometric and cultural characteristics of the study participants, and influences of modernity they had been exposed to. Knowledge and trust appeared to be significantly associated with the three threats mentioned above and the study results 'show that trust is an important determinant of risk perception even when people believe they have knowledge and control over risks (...); trust in the food system was negatively related to concern about pesticides, Salmo- 
nella, and fat, suggesting that trust may alleviate some of the concern' (Knight-Warland 2005: 272). Food-system researchers may support the discussion on food security and to ensure it they may encourage various types of partnership within the food sector. Consumers in many developed countries are concerned about safety and the nutritional value of food, environmental degradation, and the treatment of employees. Sapp and co-authors (2009) describe the consumer trust theorem as based on the estimation of 55 structural equation models to explain trust and support and give suggestions for the development of public-private partnerships in the United States. The data used to test the theorem came from two nationwide samples of adults and dealt with five areas of the U.S. food system: food safety, nutrition, treatment of workers, environmental protection, and treatment of livestock. 'The finding that fiduciary responsibility outweighs competence in understanding public trust might have a significant implication for improving approaches to risk communication. That is, the results imply that making consumers aware of the skills and expertise of food industry actors might be a key element in gaining their trust' (Sapp et al. 2009: 542).

Food insecurity can also be a subject of research in the context of group membership in a long-term perspective. In 2014, Dean, Sharkey, Nalty and Xu examined a sample of 1924 adults, aged 50 and older, in terms of the impact of intimate social capital, individual evaluations of community social capital, government capital, and interactions between social and government capital. It could be inferred that: 'Community social capital measured by individual perceptions of community life and civic quality increased with income' (Dean et al. 2014: 524). Another important conclusion was that forms of social capital associated with food-security status varied over the three income stratification groups for older adults. Survey participants in rural areas relied on gardening, hunting, and fishing more than their counterparts in urban counties.

Empowering communities provides an important topic in the context of democracy and globalization. 'It is argued that the ways in which we view and structure work, generate and disseminate knowledge through science and technology, and produce, distribute, and consume food are essential factors affecting our self-identity and the empowerment of our communities' (Lacy 2000: 3). This author discusses three areas of public work, science, and food systems with consideration given to production, distribution, and consumption of food. All those fields are crucial for building sustainable communities and a strong platform for citizens' public actions.

Social movement studies support research on alternative agrifood movements including those that focus on organics, fair trade, localism, farmers' markets, anti-GMO, animal welfare and, of course, the Slow Food movements. In turn, Friedland (2010: 601) uses the social theories of resource mobilization, strategic intervention, and structural parallelism to enhance academic discussion on these subjects. He calls for academics' involvement in agrifood movements, strongly emphasizing the significance of the activities of these movements and their ability to change how US consumers have perceived food since 1989 (Friedland 2010: 619).

In turn, the well-established periodical Sociologia Ruralis stresses the importance of more general theoretical issues. Quite unexpectedly, American authors claim that agrifood studies have the potential to discover points of convergence in the areas of social science and humanities, as indicated by recent research. For example, the theoretical approach should go beyond Actor-Network-Theory and commodity system analysis undertaking a historical overview of consumption studies. As the authors put it: 'There are many possible ways 
in which bridges between the sociology of food and agrifood studies could be built. In this respect, the current focus on knowledge systems in agriculture is extremely promising' (Goodman-DuPuis 2002: 15).

Lamine (2014: 55) goes further, pointing out that: 'The sustainability and resilience of agrifood systems are generally considered through one of two main paradigms: the sustainable development paradigm, which focuses on the interactions between agriculture and the environment, or the relocalisation paradigm which prevails in the alternative food systems' literature and in social movements' discourses. Because of its focus on direct producer-consumer relations, the relocalisation paradigm does not address the larger interdependencies in agrifood systems and thus fails effectively to reconnect agriculture and food issues. The frequent focus on alternative agrifood systems, which differ radically from the mainstream, does not help to develop pathways towards sustainability and resilience for less alternative institutions and actors'. Therefore, Lamine proposes a territorial agrifood system approach, which should be helpful in examining the processes of exclusion, the alliances involved, and the socio-ecological perspective in food studies.

Food can be treated as a cultural object, the best example being the attention that heirloom tomatoes received in the late twentieth century. 'The heirloom tomato certainly emerges as a symbol of elite status in the pages of popular magazines and newspapers by the early twenty-first century - but the act of "distinction" and the marketplace in which it happens are spatially demarcated and do not interfere with the access of nonelites to the object' (Jordan 2007: 20). These cultural changes have significant consequences for economics and the environment, resulting in the preservation of biodiversity and significant changes in the landscape as well. Family farms have gained opportunities to survive as well as develop while marking their presence in an urban environment by providing specialty and high quality foods (Jordan 2007: 37-38).

Food supply chains can be considered a dimension in rural development, which can be considered a building block for a new theory (Marsden-Banks-Bristow 2000: 424). The main conclusions are that participants in new short food supply chains need to rely heavily upon their own knowledge and networking abilities. The presented analysis ' (...) demonstrates the significance of bringing together at least four types of evolution: temporal, spatial, demand and associational or institutional' (Marsden-Banks-Bristow 2000: 436).

The sociological approach also allows for a comprehensive analysis of food as a specific product. Tregear (2003: 91-107) proposes a new insight into the category of 'typical products,' 'origin labelled products,' 'traditional foods,' 'regional speciality products,' 'artisanal products,' 'special quality,' and 'quality farm' products. All these products are conceptualized as having small-scale production, grown by local farmers, and based on natural ingredients. The author shows '(...) how food and territory are inter-related, conducted from a sufficiently broad perspective to allow alternative conceptualizations of typical products to emerge, and for the different socio-economic impacts associated with them to be assessed comparatively' (Tregear 2003: 92). She further explains: 'Overall, a broadened concept of the typical product develops: the manifestation of the links between nature and culture, shaped by the actions and value systems of actors in production and consumption domains, in turn linked to macro social, economic and political forces. Thus, all typical products represent a mixture of tradition and innovation, physicality and symbolism, mechanization and craftsmanship, endogeneity and exogeneity, myths and realities' (Tregear 2003: 104). 
Some differences between American and European approaches are due to the nature of scientific discourses. According to American traditions the approach to food studies entails practical issues concerning general recommendation for food system development and also advice for particular actors such as family farmers, local communities, or social movements. On the contrary, European tradition focuses on more general theoretical issues connected to changes from modernization to the so-called post-modernization processes.

\subsection{Food studies: intra- and extra-human approaches}

Following the issues discussed above one has to stress two types of possible analyses in the area of food studies. The first one might be seen as an intra-human approach, while the other has a feature of the extrahuman approach, i.e. focusing on social relations mostly visible in the perspectives of rural sociology, both in the American as well as the European tradition. The intra-human type of analysis encompassing nutrition, nutrition health, healthy food, etc. has been perceived as a minor one. The extra-human approach, however, seems to be a major approach with the emphasis on various aspects of social relations. In such a context food may be perceived and interpreted as a social construction, part of social networks, or an issue at social events. It definitely plays a valuable part in processes of social changes. In the following part of this paper we argue about food as an important element of rural development. Based on three different empirical cases from the Małopolska region in Southern Poland we will try to show its role in various types of rural development using some elements of the so-called neo-endogenous development theory.

The most comprehensive and clear presentation of neo-endogenous development, can - in our opinion - be found in the articles of Ray (1999, 2006: 278-291). His concept of development is founded on two premises. On the one hand, there is an endogenous element according to which the development processes must be based on local initiative and be related to an approach known from academic literature and social practice as a bottom-up approach. The 'neo' component - according to Ray - indicates that extra-local factors must play an important role in the development processes. It is not feasible, as Ray emphasizes, to guarantee integrated development at the local level by cutting local communities off from the outside world, which some extreme concepts of endogenous rural development seem to propose (Krzysztofek-Szczepański 2005).

The neo-endogenous approach to development has two primary characteristics. Firstly, the activities that occur in rural areas in pursuit of economic development are reoriented to maximize the retention of benefits within the local territory. This happens by valorizing and exploiting local resources, including both physical and human resources. Secondly, the activities that lead to development are - to use Ray's (2006: 278) wording - 'contextualized by focusing on the needs, capacities, and life perspective of local people'. The principle and process of local participation in the design and implementation of developmental practices, as well as the adoption of cultural, environmental, and 'community' values, are being emphasized here. This perspective relates to the rhetoric of local areas assuming significant influence over their own future through the use of local resources, as mentioned above and through constructing mechanisms of lasting development, initiated often by the external stimulus. 


\section{COMBINING TRADITIONS AND APPROACHES: FOOD STUDIES IN THE CONTEXT OF RURAL DEVELOPMENT}

Using all the perspectives mentioned above we will analyze three empirical cases focused on particular types of regional foods. The Małopolska region is known for its rather friendly environment for local food initiatives. As we have stressed: 'Paradoxically, such a state of affairs favours the development of distinctive local food products. Because Małopolska has such a disadvantageous agrarian structure, the majority of farmers have been forced to adopt a strategy of self-sufficiency in food and to specialize in various types of niche production' (Adamski-Gorlach 2010: 179). The particularly strong social and cultural heritage in the region is also quite significant in the context of food. Furthermore, mass tourism has played the role of an additional factor to strengthen the meaning of food in this social and cultural realm. Therefore we argue that local/regional food products should be treated as part of the cultural and territorial heritage. According to the theory of neo-endogenous development (Ray, 1999, 2006) food products can be viewed as local resources and even local amenities that, combined with various extra-local factors, might form ways of development for different communities and regions. In further analysis we will focus on the history and significance of most recognized Małopolska products, namely: the 'oscypek cheese' and 'kiełbasa lisiecka' (lisiecka sausage). According to the results of a survey (Grębowiec 2014: 70-79) almost 100\% recognized 'oscypek' as a Małopolska regional product. Moreover, $42 \%$ of investigated persons recognized 'kiełbasa lisiecka' as well. We will also describe one of the new Małopolska regional products, namely: the 'karp zatorski'.

Let us then consider three major elements of the oscypek case, namely: the history, the definition, as well as the results of the process of constructing a European Regional Product. The history of the oscypek cheese has been connected to the history of sheep husbandry in the Podhale region. It started with the old shepherd culture coming to the Podhale region from the Balkans prior to the 15th century, bringing to the region some methods of sheep grazing and sheep milk processing as well as some elements of social organization with a key position of master shepherd (baca) and younger shepherds (juhasi) being in charge of all sheep collected during the summer grazing season from the rest of farmers in the village. Baca has been personally in charge of milk processing and making cheese. The first information about sheep grazing and the production of oscypek was mentioned in historical documents as early as 1416.

However, in order to understand the current history of oscypek, one has to take two key factors into consideration. Since the beginning of the post-communist transformation many sectors of Polish agriculture, have entered a period of problems and difficulties. As a result, they have shown many crisis symptoms: the rising prices of inputs and at the same time the decreasing prices of wool and the number of sheep. At the same time, a contradictory factor has been observed as well. The mountain region has experienced a real tourist boom including also a growing number of international tourists. Moreover, the pattern of tourism changed with an extension of the winter holiday season and growing popularity of skiing. It opened a great potential market for oscypek but with some significant complications. The oscypek production season really depended on the sheep grazing season between May and September. It did not correspond with the peak in demand during the skiing season, usually from December to March. Something had to happen. As Gorlach and Adamski explain (2010: 181) 'This triggered a revolution in the oscypek cheese market. It involved "commercialization of 
tradition", driven by economic realities. "Commercialization" in this context meant improvements in the recipe. The crucial shift was from sheep's milk to cows', a modification that enabled sellers to overcome the two main structural obstacles. The limited number of sheep was no longer a problem. "Improved" oscypek could be produced all year round and therefore in the winter as well. Furthermore, since oscypek had been decoupled from shepherding, it could now be made on farms without any sheep. This led to further departures from the original technique, with the traditionally lengthy process of smoking often being reduced to just several hours, or even replaced by the procedure of steeping cheese in a tea-based blend. By implementing all these "improvements" the local community has created a large and decentralized sector for home oscypek production, located almost entirely within the sphere of the black economy'.

This tendency within the production sphere led to a distribution system that has occupied main traffic routes. It utilized street stalls as well as local food markets that became main sales points of the 'fake oscypek' 'This "fake" oscypek network is in fact something like a self-sustaining economic system' (Adamski-Gorlach 2010: 181). It is produced without any limitations or regulations and the product is sold to tourists in many places. The only issue that, first of all, characterizes such relations between producers/retailers and consumers seems to be the price of the product. Therefore the 'fake' oscypek product has reduced social relations of production, purchasing as well consumption to the pure economic event, in which the price seems to be the major (if not sole) and defining factor of the whole social situation. In this sense the so-called oscypek boom has been created.

What should now be addressed concerns the second food network. 'The second distinctive food network was created as a reaction to the above-mentioned "oscypek boom" (...) The key strategy of this second network was to satisfy the new demand' (Adamski-Gorlach 2010: 182). The 'satisfaction' policies, however, took the form of two initiatives. The first one was connected to the oscypek as a product of dairy factories, using the cows' milk to a large extent as well as pasteurized cows' milk. There are other noticeable characteristics of this second type of 'fake oscypek'. 'Products are labelled, hermetically packed and tested regularly. The name of the producer assures traceability. And, last but not least, supermarket-type oscypek is very accessible. It is being distributed through the system of grocery shops and supermarkets' (Adamski-Gorlach 2010: 182). However, the name of the product has become a main issue in the discussion. Local breeders being in favour of the preservation of tradition accused some local businessmen of unauthorized use of the product's name. The reaction from the industrial-type producers was almost immediate. 'The biggest producer of factory-made smoked cheeses from Podhale uses the name "oscypek" to market its products. Although the difference in the name amounts to only one letter, this is enough to avert accusations of illegal competition' (Adamski-Gorlach 2010: 182).

Two retail networks mentioned above seem to be of complementary character. The first one has been directed at people coming into the Podhale region. Therefore it offers its product locally, in the region, at road stands frequented by all comers, in local food places as well as on tourist tracks. The second one might be perceived as a kind of globalization (de-localization) of food case, serving the oscypek as a luxury and/or peculiar type of food in many restaurants as well as the so-called organic food shops all over Poland. 'The two food 
chains simply embrace alternative market niches. They do not compete with each other' (Adamski-Gorlach 2010: 183). However, they share one particular characteristic. Both of them use the traditional name of cheese (or its variation), but have almost nothing to do with the particular, traditional type of production. Therefore we should stress that the 'fake oscypek' is a product that may be distributed both in local shops and/or stalls as well as being a product accessible in restaurants and markets all over the country.

As if it were not complicated enough, a third network emerged connected to the 'legitimate' oscypek, i.e. the sheep cheese produced in accordance with specific rules. Fittingly, it found its proper place in the context of European Union policies focused on the certification of traditional, local, etc. types of products in order to preserve many local and/or regional traditions showing the richness of European heritage. 'The third network (...) built around oscypek cheese is also the most recent one. Its current profile has emerged from the practice of certifying traditional local food and is also dependent on oscypek as a symbol of regional tourism. New categories of actors are involved in it (...). The dominant role of local authorities and the collective representation achieved by the participating breeders has given this network a more organized character' (Adamski-Gorlach 2010: 184).

Due to the already mentioned fact that oscypek originates from the region of Podhale, located near the Tatra mountains, '(...) in the final version of the registration documents the area of the traditional oscypek production has been limited to the two administrative districts of the Podhale region (Tatrzański and Nowotarski poviats) [counties - K.G.; M.W-K; A.J-W; P.N.] and some parts of other districts to the west and north. This means that the EU-approved area of origin for oscypek is greater than the Podhale region but smaller than the actual area of production (...) The agreement left out the whole area of eastern Beskidy. Shepherds from that region cannot use the name oscypek even though their cheese meets all the standards in terms of production procedure and ingredients. The above described situation is an indication of how the "area of origin" of oscypek was more the outcome of a social construction than of geographical research' (Adamski-Gorlach 2010: 190-191).

Let us now turn to the second case, namely: the lisiecka sausage. Butchers seem to be a kind of aristocracy among the regional craftsmen in Malopolska. What is more important, they might recall their history from the year 1257 when the city of Kraków was founded. At the same time the meat trade was established as well.

The history of Kraków butchery goes back to the 16th century when the town was recognized as an important part of the European cattle trade. Therefore, the name krakowska sausage (kiełbasa krakowska) developed as an international concept used by producers in many parts of Europe and America. The word 'kielbasa' became a part of the English language, especially in the United States where it usually implies 'Polish' culinary origins. In such a context 'kiełbasa lisiecka' became one of the most important types of Polish ham and sausage products (Produkt Regionalny Kiełbasa Lisiecka [Regional Product Named Lisiecka Sausage] 2010).

The kiełbasa lisiecka is a deli product of dark brown color, with a slightly dried and slightly shiny skin. It has a rather distinct smell of pork meat seasoned with pepper, garlic, and salt. The kiełbasa lisiecka is usually made of the most tasty and delicate parts of particular types of pork meat, namely: the sirloin and selected parts of ham. They should be chopped by hand and pickled for at least 48 hours. As a result crispy portions of 
meat flavoured with white pepper as well as garlic are placed into the so-called 'trynkal' (ox bowel) of the diameter of 3-5 centimeters. Later these portions of meat go through a period of so-called 'Iying in the deck chair' for at least a week. Next, they are formed into small loops and go through the processes of drying, smoking and/or roasting for several hours. In this particular process only traditional and well-tested methods have been used. One of the requirements is that the only source of heat and smoke comes from the chunks of fruit trees and in some cases beech and/or alder.

The use of any chemicals is strictly forbidden in the whole process, quite contrary to typical modern, standard meat productions. The recipe, coming from - as the tradition says - the 16th century was discovered by one of the Krakow butchers in 1930s. Since then the art of sausage production has been continued by butchers from two communities, namely: Liszki and Czernichów, located exactly on the outskirts of the city of Kraków. Currently, the product is under the protection of EU law thanks to the initiative of the association called Konsorcjum Producentów Kiełbasy Lisieckiej (The Lisiecka Sausage Producer Consortium) established in 2004. This is an extremely exclusive producer group consisting of only nine (!) producers from Liszki and Czernichów communities.

Let us try to complete this part of our consideration with the third case, namely: the 'zatorski karp'. Carp is a very popular fish in Poland. Nobody can imagine Polish cuisine without carp, especially the traditional Christmas Eve supper in Poland. In earlier times carp was served in the houses of rich and influential families in Poland, including the royal court. The region of Małopolska might have been recognized as a centre of carp breeding since early medieval times in order to supply the royal court in Kraków. The carp was mentioned in the 16th century by the famous Polish chronicler Jan Długosz. It should also be mentioned that at that time carp had been an important part of various heraldries of Polish knights (Produkt Regionalny Karp Zatorski [Regional Product Named Zatorski Carp] 2007).

The beginnings of the history of carp cultivation in Poland are not quite clear. Most likely, it was Cistercian monks who established the breeding ponds for carp as part of their economic activities. The Cistercian monks were pioneers in introducing many new techniques and procedures in agricultural and fishery productions. One of the carp breeding centres was started in the community of Zator, west of Kraków, almost on the border between the Małopolska region and Silesia. The latter became an important area of industrial production with coal mining, steel-works as well as chemical industries.

One should also stress that today the zatorski (Zator area) carp has not been a typical type of a breed. Quite to the contrary, it is a (hybrid of various types of carp fish. Its origins come not only from the local breed but also from Hungary, the Balkans, as well as even Israel. As a result the zatorski carp of today is a blue-olive fish, with a curved back. It is a fast growing breed with a relatively big mass of meat. Among its other characteristics one should stress a delicate taste and fresh as well as a nice fish smell. It should also be added that typical carp fish should weigh from 1100 to 1800 grams (Stowarzyszenie Dolina Karpia [Carp Valley Association] 2015). It should be noted here that the breeding of zatorski carp requires a clean environment with numerous plants and some animal breeds protected against extinction. It is also worth mentioning that the beginnings of fishery production in the Zator area date back to the 16th century while the fishery economy can be traced to the 12th 
century. The oldest ponds were constructed by Tartar prisoners of war. These ponds have been named after some famous families living a long time ago in the area (famous Boner family of Krakow) or from the names of their societal position (kasztelan, starosta). The popularity of zatorski carp comes mainly from the long-lasting tradition of breeding, knowledge and practices concerning fish production, etc. Contemporary breeders have been heirs of people involved in fish production business for a long time. This is the reason that they have been named as 'karpiki' or 'karpiany', which means carp breeders.

Today the production of zatorski karp has been conducted in the area of three different local communities (gmina), namely: Zator, Przeciszów and Spytkowice. The communities have become an important recreation area in the western part of Małopolska, located in between the Kraków agglomeration and the industrial Silesia region, as mentioned earlier. Currently, the whole 'Karp Valley' project has gained regional, if not nationwide, recognition. However, the essential part of the carp breeding and production seems to lie in the fact that almost all parts of it are done manually without introducing elements of industrial fishery production. There are also special events organized in order to promote karp zatorski. Each year the beginning of July becomes a major socio-cultural event in the region and is celebrated as the Days of Zatorski Carp. The festivities include presentations of work by local and external artists, rural NGOs as well as other local food producers (Dolina Karpia [Carp Valley] 2015).

\section{DISCUSSION AND CONCLUSIONS}

In the broadest terms, the situation of many local and regional products has to be seen in the context of food culture transformations at the national level (Adamski-Gorlach 2010). Poland with its rich and diversified culinary culture had been able to overcome the communist period (1944-1989) with its tendencies to provide the mass population with rather standardized types of foods in the contexts of rapid industrialization as well as urbanization. Major results of such changes have demolished many social relations or a lot of traditional institutions but not some peculiar areas of local cultures and traditions. Therefore we might argue that some traditions of particular local foods have survived mainly in families located especially in rural communities.

Such discussions seem to be properly framed inside some general food-consumption debates. In recent work Adamski and Gorlach (2010: 175) note that 'theoretical debates over food production and consumption seem to involve at least three basic streams of discussion and thought'. For these authors 'the notions of territoriality, quality and tradition introduce a new conception of food that seems to be an alternative or a challenge to the standardized products perceived as commodities produced in the industrial agricultural sector' (Adamski-Gorlach 2010: 175). The first stream of thought they address is the one connected to the issue of tradition. In this particular context one can distinguish the de-territorialization as well as re-territorialization of food as being two sides of one proverbial coin. It is not surprising that in the era of industrialization and urbanization the massive processes of food de-territorialization have taken place. However, in the era of post-industrial development the processes of food re-territorialization might be pointed to as part of the new patterns of human development infiltrating some parts of tradition and some efforts to overcome the mass production approach of the industrial era. As Tregear (2003: 91) stresses, special food products have strong ties with particular territories. 
Such a 'placement' of foods might be also connected to another characteristic, namely, the quality. It is strengthened in literature: 'In broad terms, the catalyst and fundamental theme of the Western European AAFN [Alternative Agriculture Food Networks - K.G.; M.W-K; A.J-W; P.N.] literature is the perception of a "turn" by consumers away from industrial food provisioning towards quality' (Goodman 2004: 4).

Such a perspective based on the contradiction between regular, industrial-type food networks as well as this of an alternative one has resulted in a few important consequences (see for more: Adamski-Gorlach 2010: 175-178). First of all, we have to stress the particular duality of observed food chains and/or networks. Moreover, we cannot treat them as disjunctive ones. Quite to the contrary, they should be mentioned as complementary contributions to the whole system of food production, distribution, and consumption. However, there is one particular component (among the three, namely: tradition, quality, and territoriality) that seems to be especially important for our further analysis.

As expected, the presented regional products confirm our initial assumption to be an important part of the local development. The oscypek cheese plays an important part in the food economy of the Podhale region and contributes to the attractiveness of the area as a tourist destination. In turn, the case of kiełbasa lisiecka highlights the role of small food initiatives occurring on the outskirts of large cities. Here the importance of close rural-urban relations as a vital part of rural development is undeniable. This is also true for the karp zatorski case. This particular traditional food product has to be perceived as a certain driving force in rural development fostering the ties between the leisure and recreation area and major urban and industrial spaces. The example of carp zatorski shows how the local production of food enables direct access to fresh, minimally processed food that does not contain chemical ingredients so typical for mass production of food and advanced processing (Krelowska-Kułas, 2001). Production of local and regional foods is known to have a positive impact on the increase of employment, incomes, and other economic results in particular communities (O'Hara 2012). 


\section{REFERENCES}

Adamski, T. - Gorlach, K. (2010) One Tradition, Many Recipes: Social Networks and Local Food Production - The Oscypek Cheese Case. In Fonte, M. - Papadopoulos, A. G. (eds.) Naming Food After Places. Food Relocalisation and Knowledge Dynamics in Rural Development. Farnham, Surrey and Burlington, VT: Ashgate, 173-195. https://doi.org/10.4324/9781315597195.

Albala, K. (ed.) (2014) Routledge International Handbook of Food Studies. Routledge Taylor \& Francis Group, London and New York. https://doi.org/10.4324/9780203819227

Bauman, Z. (1993) Post-modern Ethics. Oxford, UK/Cambridge, USA: Blackwell.

Buccini, A. F. (2014) Linguistics and food studies: structural and historical connections. In Albala, K. (ed.) Routledge International Handbook of Food Studies. Routledge Taylor \& Francis Group, London and New York, 146-158.

Bower, A. - Piontek, T. (2014) Food in film. In Albala, K. (ed.) Routledge International Handbook of Food Studies. Routledge Taylor \& Francis Group, London and New York, 177-186. https://doi.org/10.4324/9780203819227

Cargill, K. (2014) Historical background of food scholarship in psychology and major theoretical approaches in use. In K. Albala (ed.) Routledge International Handbook of Food Studies. Routledge Taylor \& Francis Group, London and New York, 39-47. https://doi.org/10.4324/9780203819227

Chrzan, J. (2014) Nutritional anthropology. In Albala, K. (ed.) Routledge International Handbook of Food Studies. Routledge Taylor \& Francis Group, London and New York, 48-64. https://doi.org/10.4324/9780203819227

Dean, W. R. - Sharkey, J. R. - Nalty, C. C. - Xu, J. (2014) Government Capital, Intimate and Community Social Capital, and Food Security Status in Older Adults with Different Income Levels. Rural Sociology 79(4), 505-531. https://doi.org/10.1111/ruso.12047

Dirks, R. - Hunter, G. (2014) The anthropology of food. In Albala, K. (ed.) Routledge International Handbook of Food Studies. Routledge Taylor \& Francis Group, London and New York, 3-15. https://doi.org/10.4324/9780203819227

Dufour, D. L. - Goodman, A. H. - Pelto, G. H. (eds.) (2000) Nutritional Anthropology: biocultural Perspectives on Food and Nutrition. Mountain View, California: Mayfield Publishing Company.

Drewnowski, A. (1996) The behavioral phenotype in human obesity. In Capaldi, E. D. (ed.) Why we eat what we eat: The psychology of eating. American Psychological Association, Washington, DC, 291-308. https://doi.org/10.1037/10291-000

Friedland, W. H. (2010) New Ways of Working and Organization: Alternative Agrifood Movements and Agrifood Researchers. Rural Sociology, 75(4), 601-627. https://doi.org/10.1111/j.1549-0831.2010.00031.x

Fitzpatrick, J. (2014) Food and literature: an overview. In Albala, K. (ed.) Routledge International Handbook of Food Studies. Routledge Taylor \& Francis Group, London and New York, 122-134. https://doi.org/10.4324/9780203819227

Goodman, M. K. (2004) Reading Fair Trade: Political Ecological Imaginary and the Moral Economy of Fair Trade Foods. Political Geography 23, 891-915. https://doi.org/10.1016/j.polgeo.2004.05.013

Goodman, D. E. - DuPuis, M. (2002) Knowing Food and Growing Food: Beyond the Production-Consumption Debate in the Sociology of Agriculture. Sociologia Ruralis, 42/1, 5-22.

Goodman, D. E. - DuPuis, M. - Goodman, K. (2014) Alternative Food Networks. Knowledge, practice, and politics. London and New York: Routledge. https://doi.org/10.4324/9780203804520

Grębowiec, M. (2014) Rola produktów tradycyjnych i regionalnych w budowaniu konkurencyjnej oferty regionu małopolskiego w Uni Europejskiej na przykładzie „Obwarzanka Krakowskiego” [The role of traditional and regional products in building a competitive offer of the Małopolska region in the Europen Union on the example of „Obwarzanek Krakowski”] In Problemy Rolnictwa Światowego, Tom 14 (XXIX) 2014 Zeszyt2, Warszawa: Wydawnictwo SGGW, 70-79.

Grumett, D. (2014) Food and theology. In Albala, K. (ed.) Routledge International Handbook of Food Studies. Routledge Taylor \& Francis Group, London and New York, 159-168. https://doi.org/10.4324/9780203819227

Heldke, L. (2014) Philosophy and food. In Albala, K. (ed.) Routledge International Handbook of Food Studies. Routledge Taylor \& Francis Group, London and New York, 135-145. https://doi.org/10.4324/9780203819227

Jordan, J. A. (2007) The Heirloom Tomato as Cultural Object: Investigating Taste and Space. Sociologia Ruralis, Vol 47, Number 1 , 20-41. https://doi.org/10.1111/j.1467-9523.2007.00424.x

Kirschenmann, F. L. (2014) Anticipating a new agricultural research agenda for the twenty-first century. In Albala, K. (ed.) Routledge International Handbook of Food Studies. Routledge Taylor \& Francis Group, London and New York, 364-370. https://doi.org/10.4324/9780203819227

Knight, A. J. - Warland, R. (2005) Deter minants of Food Safety Risks: A Multi-disciplinary Approach. Rural Sociology 70(2), $253-275$. https://doi.org/10.1526/0036011054776389

Krelowska-Kułas, M. (2001) Chemiczne zanieczyszczenia żywności. Zeszyty Naukowe Akademii Ekonomicznej w Krakowie, nr. 572, 39-5. 
Krzysztofek, K. - Szczepański M. S. (2005) Zrozumieć rozwój - od społeczeństw tradycyjnych do informacyjnych : podręcznik socjologii rozwoju społecznego dla studentów socjologii, nauk politycznych i ekonomii. Katowice: Wydawnictwo Uniwersytetu Śląskiego.

Lacy, W. B. (2000) Empowering Communities Through Public Work, Science, and Local Food Systems: Revisiting Democracy and Globalization. Rural Sociology, 65(1), 3-26. https://doi.org/10.1111/j.1549-0831.2000.tb00340.x

Lamine, C. (2015) Sustainability and Resilience in Agrifood Systems: Reconnecting Agriculture, Food and the Environment. Sociologia Ruralis, Vol 55, Number 1, 41-61. https://doi.org/10.1111/soru.12061

Lizie, A. (2014) Food and communication. In Albala, K. (ed.) Routledge International Handbook of Food Studies. Routledge Taylor \& Francis Group, London and New York, 27-38. https://doi.org/10.4324/9780203819227

Marsden, T. - Banks, J. - Bristow, G. (2000) Food Supply Chain Approaches: Exploring their Role in Rural Development. Sociologia Ruralis, Vol 40, Number 4, 424-438. https://doi.org/10.1111/1467-9523.00158

McIntosh, W. A. (2014) The sociology of food. In Albala, K. (ed.) Routledge International Handbook of Food Studies. Routledge Taylor \& Francis Group, London and New York, 14-26. https://doi.org/10.4324/9780203819227

Moore, K. M. (2014) The archaeology of food. In Albala, K. (ed.) Routledge International Handbook of Food Studies. Routledge Taylor \& Francis Group, London and New York, 74-86. https://doi.org/10.4324/9780203819227

Murray, S. (2014) Food and television. In Albala, K. (ed.) Routledge International Handbook of Food Studies. Routledge Taylor \& Francis Group, London and New York, 187-198. https://doi.org/10.4324/9780203819227

Nygard, T. (2014) Food and art. In Albala, K. (ed.) Routledge International Handbook of Food Studies. Routledge Taylor \& Francis Group, London and New York, 169-176. https://doi.org/10.4324/9780203819227

O'Hara, J. (2012) Successful Development of Local and Regional Food Systems. The New England Story. Communities \& Banking, vol. 23, no.1, 11-13.

Ray, C. (1999) Towards a meta-framework of endogenous development: repertoires, paths, democracy and rights. Sociologia Ruralis, 4 (39), 521-537. https://doi.org/10.1111/1467-9523.00122

Ray, C. (2006) Neo-endogenous development in the EU. In Cloke, P. - Marsden, T. - Mooney, P. H. (eds.) Handbook of Rural Studies, London: Sage. https://doi.org/10.4135/9781848608016

Rosner, H. - Hesser A. (2014) Journalism. In Albala, K. (ed.) Routledge International Handbook of Food Studies. Routledge Taylor \& Francis Group, London and New York, 89-100. https://doi.org/10.4324/9780203819227

Rosset, P. M. (2006) Food is Different. Why We Must Get the WTO Out of Agriculture. London \& New York: Zed Books.

Sapp, S. G. - Amot, Ch. - Fallon, J. - Fleck, T. - Soorholtz, D. - Sutton-Vermeulen, M. - Wilson, J. J. H. (2009) Consumer Trust in the U.S. Food System: An Examination of the Recreancy Theorem. Rural Sociology, 74 (4), 525-545. https://doi.org/10.1111/j.1549-0831.2009.tb00703.x

Spark, A. (2014) Public health nutrition. In Albala, K. (ed.) Routledge International Handbook of Food Studies. Routledge Taylor \& Francis Group, London and New York, 65-73. https://doi.org/10.4324/9780203819227

Tregear, A. (2003) From Stilton to Vimto: Using Food History to Re-think Typical Products in Rural Development. Sociologia Ruralis, Vol 43, Number 2, 91-107. https://doi.org/10.1111/1467-9523.00233

Valenze, D. (2014) The cultural history of food. In Albala, K. (ed.) Routledge International Handbook of Food Studies. Routledge Taylor \& Francis Group, London and New York, 101-113. https://doi.org/10.4324/9780203819227

Wrangham, R. W. (2009) Catching Fire: How Cooking Made Us Human. Basic Books: New York.

Young, E. M. (2012) Food and Development. Routledge: London and New York. https://doi.org/10.4324/9780203877487

\section{INTERNET SOURCES}

Dolina Karpia 2015, Europejski Fundusz Rolny na Rzecz Rozwoju Obszarów Wiejskich, 19.12.2015, <http://zasobydolinykarpia.dolinakarpia.org/>

Produkt Regionalny Kiełbasa Lisiecka 2010, Ministerstwo Rolnictwa i Rozwoju Wsi, 19.12.2015, < http://www.minrol.gov.pl/Jakosc-zywnosci/Produkty-regionalne-i-tradycyjne/Lista-produktow-tradycyjnych/woj.-malopolskie/Kielbasa-lisiecka >

Produkt Regionalny Karp Zatorski 2007, Ministerstwo Rolnictwa i Rozwoju Wsi, 19.12 .2015 < http://www.minrol.gov.pl/Jakosc-zywnosci/Produkty-regionalne-i-tradycyjne/Lista-produktow-tradycyjnych/woj--malopolskie/Karp-zatorski >

Stowarzyszenie Dolina Karpia 2015, 19.12.2015, < http://gruparybacka.dolinakarpia.org/ > 